\title{
The Sport for All Ideal: A Tool for Enhancing Human Capabilities and Dignity
}

Authors' contribution:

A) conception and design of the study

B) acquisition of data

C) analysis and interpretation of data

D) manuscript preparation

E) obtaining funding

\section{Francisco Javier López Frías}

University of Valencia, Spain

\section{KEYWORDS}

ABSTRACT
Sport, as a child of modernity, is intertwined with typically modern elements, such
as the search for universality, competition, and the fascination for measurement. As
modernity is essentially defined, in legal and moral terms, as a search for universally
grounded moral principles or basic human rights, modern sports are widely seen as a
means to promote typically modern values such as dignity. This paper conceives of
the term "dignity" in light of the capabilities approach upheld by Martha Nussbaum
and Amartya Sen. According to these authors, dignity is conferred according to
certain human basic capabilities that we all are entitled to. This is the reason why
this article explores how sport can be a tool for enhancing and exercising such
human capabilities. In so doing, I shall argue that the Sport for All ideal provides us
with a normative proposal to achieve such a task since it embodies the basic spirit
and ethical goals of our modern society. Moreover, connecting the promotion of
dignity to the capabilities approach will allow us not just to use sport as a means for
development, but also to provide us with specific criteria to evaluate the impact of
sport in the wider society regarding the promotion of people's dignity.
sport for all, philosophy of sport, olympism, human development, capabilities
approach

\section{Sport as a tool for development}

Many international associations see sport as a means of achieving non-sporting outcomes. One such institution is UNESCO. Its Declaration on Sport underlines that sport is a worldwide social phenomenon deeply rooted in the young and adult lives of men and women. They go so far as to include the following words in their declaration: "It is closely linked to the problems upon whose solution the future of our civilization depends." So sport must be understood not as a by-product of our society, but as an engine. In line with this proposal, the European Union says in The European Sport Charter that one of the main goals of sports is:

"to protect and develop the moral and ethical bases of sport and the human dignity and safety of those involved in sport, by safeguarding sport, sportsmen and women from exploitation for political, commercial and financial gain and from practices that are abusive or debasing 
including the abuse of drugs and the sexual harassment and abuse, particularly of children, young people and women" (Article 1, ii).

Furthermore, the Olympic Charter states that

"The goal of Olympism is to place sport at the service of the harmonious development of man, with a view to promoting a peaceful society concerned with the preservation of human dignity" (Preamble, 2).

Sport thus conceived plays an important role not just in the course of our societies, but in our development as human beings. In fact, it is connected with the concept that captures our most basic essential features: "dignity". In line with this idea, the 1948 United Nations Declaration of Human Rights conceives "the right to rest and leisure" as a human right. This right grounds both the Sport for All campaign launched for the first time in Norway in 1966 (Beashel \& Taylor, 1996, p. 350) and the idea that practicing sport is a human right - though it might be a "forgotten right". Accordingly, sport is thought of as a promoter of both human development and dignity.

Philosophers and educators have bought this interpretation of sport as a means of human development. Thus, as interpreters, authors in philosophy conceive sport as a "mutual quest for physical excellence" (Simon, 2007, p. 250); such a practice is not only about competition and victory. Rather, sport gives us the opportunity to assert human qualities and to reach self-development through struggle and effort. According to Jim Parry, physical education activities "act as a context for the development of human excellences and 'virtues' and the cultivation of those qualities of character which dispose one to act virtuously" (2007, p.198). In Frans De Wachter's (2002) words, "they create a favorable climate in which human flourishing is possible".

As Roger Levermore and Aaron Beacom (2009) show, many social theorists see sport as a tool for social change. Sporting activities and institutions have the capacity to act as agents of change, as opposed to reflecting wider social change. Thus, proponents of sport-for-development policies usually distinguish between "sport-plus" and "plus-sport" programs. The major aim of sport-plus policies is to develop sustainable and successful sporting organizations. In contrast, plus-sport programs use sport as a means of achieving non-sporting outcomes; sport thus understood is a means toward human development.

However, as Dominique Bodin and Gaëlle Sempé (2011) and Verner Møller (2011) point out, "sports are no more ethical or virtuous in essence than they are inherently evil". We cannot downplay this "dark side" of sports. We are into a new millennium that is dominated by perpetual war, financial crises, enhanced security, terror threats, commercialization of many spheres of life (...). As popular cultural forms, sporting practices and institutions find themselves structured into and through this context: doping, violence, bribery, match fixing, and corruption are some of the evils resulting from such a context. Thus, Kevin B. Wamsley (2004) argues that terms at the core of the humanistic conceptions of sports, such as "preservation of dignity" or "harmonious development", are metaphoric or empty.

It is worth noting that Parry, in his quotation above, employs the term "physical education activities" instead of "sport". I believe that Parry does so because he is aware that employing the word "physical (education) activities" rather than "sport" makes a big difference. However, not many theorists employ this distinction between "physical education"—or "physical exercise"-and "sport". Sport is an ambiguous term. Some argue that it is about non-sporting goals, such as education, human flourishing, and development, while others argue that it is about plain victory, money, and records. This is also the reason why some authors speak about "sport-for-all" as a different way of practicing exercise, that is to say, as something categorically different from sport. As the main goal of sport-for-all "contests" is not to set a context for the mutual quest for physical excellence, but to foster everybody's participation in sport, the competitive nature of sport would disappear as well as sport in itself.

In contrast to this idea, I will argue that there is no necessary - or logical - connection between the application of the Sport for All ideal and the downplaying of the basic tenets of sport. As the Sport for All ideal pursues the creation of new opportunities for those who want to engage in sport by empowering them - 
for instance, article 1 of the European Sport for All Charter states that "[e]very individual shall have the right to participate in sport"- it does not damage the constitutive elements of sport, especially, competitive elite sport - in fact, it could be argued that the Sport for All ideal has the potential to maintain and protect its integrity.

\section{Human rights, sport, and development}

Sport, as a child of modernity, is intertwined with typically modern elements, such as the search for universality, competition, and the fascination for measurement. As modernity is essentially defined, in legal and moral terms, as a search for universally grounded moral principles or basic human rights, modern sports are widely seen as a means to promote typically modern values like dignity. However, there are two important questions here that need to be answered: How should we define "dignity"? What elements are indicative of human dignity?

Most international associations try to answer to both questions by appealing to human rights. Therefore, from a development-promoting point of view, sport's main goal is to promote dignity by fostering and protecting human rights. For example, as Richard Giulianotti's 2004 paper "Human Rights, Globalization and Sentimental Education: The Case of Sport" shows, the UN organized in February 2003 an "International Conference on Sport and Development" whose main conclusion was that international organizations should utilize sports to achieve social goals such as promoting human rights and human dignity. As a consequence of this decision, several international organizations have introduced sport-related policies to promote development. Here are some examples:

"1. The Red Cross employed famous athletes to publicize its anti-personal mines campaign.

2. The IOC has assisted victims of genocide in Rwanda.

3. The International Labor Organization launched the "Red Card to Child Labor" campaign.

4. The "Red Deporte y Cooperación" campaign was launched with the aim of promoting development in developing countries.

5. "Fútbol para la Paz" was established in Colombia to rehabilitate and reintegrate the drugaddicted” (Giulianotti, 2004, p. 356.)

The impulse given to the Sport for All campaign during the 1960s is a by-product of the project of using sport as a means of improving human beings' quality of life. However, there is the danger that sportgoverning institutions use these campaigns and policies as smokescreens to hide their real nature and interests. For example, some of the campaigns launched in developing countries by elite football teams are a simple means of talent scouting. As Fred Coalter (2010) shows, most of these projects, even those launched by local people, try to finance themselves by exporting young talented athletes to developed countries, which means that their main goal is not solely "humanitarian", but also economic. Thus, there is always the risk for them to lose sight of humanitarian goals entirely in favor of profit-making.

By drawing on the plus-sport/sport-plus distinction, these projects fall into the category of "sport-plus projects" that attempt to produce some goods for the community by creating a solid sporting structure first. The economic and sporting goals come first, and then a part of the benefits is used to improve the living conditions of a given society. Nonetheless, this is not enough; charitable measures alone do not suffice (Kreft, 2014). For the sport-for-development projects to be truly effective or truly humane, to put it in a different way, their "humanistic outcomes" should extend beyond those positive effects derived from economically and sportingly successful projects. Rather, they need to be integrated into the particular communities that we want to improve. This is the one of the basic tenets of the Sport for All Charter:

"Sport, being an aspect of socio-cultural development, shall be related at local, regional and national levels to other areas of policy-making and planning such as education, health, social service, town and country planning, conservation, the arts and leisure services" (European Sport for All Charter, Article 3). 
Regarding this idea, Coalter (2010) shows how the Mathare Youth Sport Association (MYSA) tried to achieve this goal by linking sport to community service, such as creating teams to clear drains, cut grass, and remove litter. The core value of these activities is to emphasize the sportspeople's collective responsibilityand reciprocity - for their communities. For Coalter, this is an effective way to place "social capital" (or "public opinion") at the center of the sport-for-development campaign.

Regrettably, there are not many examples like the one mentioned above. Profit-making is the driving force of sporting organizations; human rights is not a priority for them. According to Giulianotti, the comparison of sporting organizations' internal budgets is also instructive for analyzing the rhetoric of human rights that hides sport-governing bodies' interests:

"For example, FIFA's humanitarian support fund has an annual budget of two million Swiss francs (around £907.000) (...). Compare that budget to the $£ 5$ million spent by FIFA's inner circle over six weeks in Paris during the 1998 World Cup finals" (2004, p. 359).

Furthermore, following Giulianotti's claims, international sport-governing bodies, which try to sell themselves as organizations caring for fostering and safeguarding peoples' dignity and well-being, do not match most of the requirements revealed, for instance, by the 1948 Declaration of Human Rights:

“Article 1 emphasizes that 'all human beings are born free and equal in dignity and rights'. Sports governing bodies tend to ignore egalitarianism by prioritizing elite athletes in resource allocation (...). Article 10 states that 'everyone is entitled in full equality to a fair and public hearing by an independent and impartial tribunal', but sport's 'disciplinary procedures' against athletes are often adjudicated by officials in private. Article 18 insists that 'everyone has the right to freedom of thought, conscience and religion', but sports governing bodies traditionally take a harsh stand on those who are deemed to 'bring politics into the stadium' [Besides] sports governing bodies habitually restrict freedom of expression by disciplining those who criticize officials and procedures (...). Article 26 stipulates that 'everyone has the right to education', which 'shall be directed to the full development of the human personality'. Historically, among youth athletes, specialization in sports disciplines with a view towards entering elite levels has invariably led to a serious deficit in other forms of education that would otherwise promote their personal and social development" (Giulianotti, 2004, pp. 360-361).

I will introduce one caveat. Modern sports are not solely played within the framework of elite sports organizations and competitions. There is a broader set of activities, such as amateur and youth sports, that are referred to as "modern sport" as well. Therefore, although the task of promoting human rights seems to be at odds with the main goals of elite sport organizations, modern sports could still be a means of human development. However, we first have to clarify what human development is about.

\section{Sport and development-as-freedom: A philosophical proposal}

Although many international institutions maintain that sports should be seen as a means for achieving the wider social outcome of protecting and fostering the human rights, the language of human rights is not the most accurate in order to figure out how sports can be a tool for development. This is the reason why some institutions, such as the United Nations and the US International Council on Disabilities (Grant, 2011), think of sports as a tool to promote and maintain human dignity.

Dignity, in line with the capabilities approach, should be conferred on the basis of a universally shared set of human capabilities. Then, for sport to promote and enhance dignity, it has to refer to such basic capabilities. Human capabilities, thus, provide us with a specific tool to evaluate the application of sport-fordevelopment projects. They work better than human rights. Constitutions are full of fundamental rights that are not backed up by the state's action. They are just ineffective words written down on paper. In contrast, thinking in terms of capabilities gives us an example of something more concrete. This is the motif behind the following Bernard Williams's claim: 
"I am not very happy myself with taking rights as the starting point. The notion of a basic human right seems to me obscure enough, and I would rather come at it from the perspective of basic human capabilities. I would prefer capabilities to do the work, and if we are going to have a language or rhetoric of rights, to have it delivered from them, rather than the other way around" (quoted by Nussbaum, 1997, p. 278).

However, there is a relation between fundamental rights and capabilities. As Amartya Sen (2005) argues, both of them go well with each other since they have elements in common, but they also differ in some ways; human rights and capabilities cannot be subsumed entirely within the other. Thus, as capabilities and human rights are not identified, sports can be seen as tools for development, even in the case that the project of using sports as a means for promoting human rights was considered misguided.

Capabilities are better than rights in practical terms. In fact, the notion of "development" is currently understood within philosophy in light of the above-mentioned capabilities approach sketched by Amartya Sen and Martha C. Nussbaum. Leaders of countries and international institutions often focus on national economic growth in order to measure development. They maintain that increasing gross domestic product (GDP) makes a difference in people's life. However, the United Nations Development Programme (UNDP) has utilized the capabilities approach's conception of development to measure countries' level of development. As Nussbaum argues, the UNDP maintains that "the real wealth of a nation is its people" (2011, p. 1).

The main purpose of the capabilities approach is to respond the following two questions: a) what are people actually able to do and to be? and $b$ ) what real opportunities are available to them? The real concern of this theory is the quality of human life, and its main goal is to empower people to have "the kind of life they have reason to value". To do so, the capabilities approach claims that societies should promote a set of substantial freedoms called "capabilities" that are required for having a life worthy of dignity. This is what development is about.

Dignity, freedom, and capabilities are strongly connected with each other in the capabilities approach. Following Immanuel Kant's notion of dignity, such an ethical proposal takes each person as an end by asking about the opportunities available to him or her. Options are freedoms, and freedom has an intrinsic value, which is at the basis of dignity. For persons to have a life worthy of dignity, they have to be entitled to a certain set of opportunities. According to R. Dixon and Martha C. Nussbaum, a life worthy of dignity requires, at a bare minimum, "an ample threshold of ten central capabilities - or opportunities" (2011, p. 2). Thus, the implementation of human development policies must go beyond economic parameters and focus on the above-mentioned ten capabilities ${ }^{1}$ - that is to say, they must keep and foster those capabilities upon which dignity is conferred. (See Appendix I.) As the capabilities approach's concept of development has proven to be both useful and fruitful in practical terms, I will draw on it to analyze whether or not sport is a means of human development.

\footnotetext{
1 Martha C. Nussbaum clarifies the particular nature of such capabilities. She distinguishes between internal capabilities, basic capabilities, and (combined) capabilities. Capabilities are "not just abilities residing inside a person but also the freedoms or opportunities created by a combination of personal abilities and the political, social, and economical environment" (Nussbaum, 2011, p. 20). The term "internal capabilities" refers to developed and trained skills developed in interaction with the social, economic, and political environment. They are not mere innate powers and skills, which she calls "natural capabilities". "Combined capabilities", which are usually called "capabilities", are then "internal capabilities plus the social/political/economic conditions in which functioning can actually be chosen" (Nussbaum, 2011, p. 22). The following example illustrates this distinction: a society might promote quite well the internal capacity of free speech, but then deny people free expression in practice through repression of speech (Nussbaum, 2011, p. 21). We should establish a distinction between "well-being/welfare" (Conill, 1998) in order to clarify the role of the states regarding the implantation of policies based on the capabilities approach. In his book Commodities and Capacities, Sen makes a distinction between what we are free to do and to be, and the material goods and actual freedoms that we have. Well-being is related to the former, while welfare to the latter. According to the capabilities approach, institutions and decision-makers should care more about people's well-being and less about their welfare.
} 


\section{Sport, capabilities, and human development: The Sport for All campaign}

The previous section stated that human development is beyond mere financial terms and goals. Moreover, by following the capabilities approach, it stated that human development must refer to a basic set of freedoms - capabilities - that we all deserve in order to lead a life worthy of dignity. In this section, we shall analyze how modern sport can help us maintain and foster such a basic set of capabilities.

The task of analyzing how sport might promote each capability on the list will take us too far away from the main goal of this paper. Given these limitations, I will focus my analysis on how modern sports can promote certain capabilities by focusing on those capabilities that Nussbaum takes to be of special importance "because they (...) organize and suffuse all the other capabilities, making their pursuit truly human" (2011, p. 288) - namely, practical reason and affiliation. To me, these capabilities play an essential role in our democratic societies, so it could be said that they are at the basis of peoples' democratic spirit. Regarding this topic, the philosopher Henning Eichberg (2010) asks "How the people of democracy are related to the people of sport? " in order to think of sports in the context of a philosophy of democracy.

By following Eichberg's work, I will analyze how sports can promote the above-mentioned two capabilities relating to peoples' democratic spirit. As Parry (2007) shows, democracy is an embodied practice related to self-determination, recognition of others, and togetherness. So:

"democratic life is based on how people play together, learn from each other, sing together,

laugh, hold festivity, move in green nature and so on" (Eichberg, 2010, p. 4).

All these activities have a bodily dimension, which is the very dimension promoted in sport. Thus, sporting activities are a means of living democracy from below.

Eichberg also acknowledges that the term "sport" has become less clear. Its limits with respect to the other physical activities have become blurred. So he distinguishes between elite sport (or sport), gymnastic activities, and popular games. Each of these activities develops in accordance to the relationships that arise between the persons who perform them. For example, sports are dominated by instrumental rationality and specialization. Gymnastic activities stress discipline and fitness. And popular games' main goal is to display and exaggerate differences.

According to Eichberg, it is those activities that we term "Sports for All" that best suit the goal of educating people in democracy and, following my proposal, empowering and capacitating them. For example, Coalter (2010) uses the example of football matches in which only women can score. This practice is not purely sport since some of modern sports' tenets, such as equality in competition, have been changed for educative purposes. However, this new version of football suits better the purpose of teaching values and empowering women than usual football competitions where the weakest members of the team have no chance to become and feel important.

The main consequence of Eichberg's thesis is that the best way to use sports and physical activities to increase human capabilities is not through the common campaigns employed by sporting organizations, such as creating competitions to give young people the opportunity to practice sport, but through the display of public spaces in which individuals can bond, laugh, move, play together: that is to say, by using sporting activities as a means - and a field - for promoting social and peaceful interaction ${ }^{2}$.

According to Eichberg's analysis, the Sport for All ideal contains valuable qualities to educate people:

a) Enlightening qualities such as self-expression, concentration, self-dedication, and sacrifice. For example, according to Kant, practical reason is based on the regulative use of reason for human practice. This regulative role is played by the categorical imperatives, which are "unconditional requirements that assert their authority in all circumstances". For Kant, practical reason is the ability to act according to those

\footnotetext{
${ }^{2}$ At this point, the philosophy of sports meets that new discipline within sport sciences that is called "the geography of sport", which focuses on the study of the spatial environment as an essential component of sporting activities.
} 
maxims that should become universal laws. Self-sacrifice, concentration, and self-dedication seem to be at the base of practical reason understood in a Kantian sense.

b) People develop a common rhythm through the sporting activity and in the sporting fields. Sport is a practical way of creating dialogic interaction among people. It is a place for social encounter. Individuals not only encounter themselves by experiencing different types of movement and unexpected practical situations. Rather, they meet others and experience that sport is not done by isolated athletes (producers), but by all the participants and members of the sporting community. This is the reason why Warren Fraleigh (1984) argues for understanding the opponent as a partner or a colleague instead of as a rival or an obstacle to overcome. According to this interpretation of sport, sports are a source of affiliation.

Further research, especially empirical research, on the ways to promote human capabilities - and human development - through sport is needed. As Eichberg shows, some qualities of Sport for All activities help us promote at least two human capabilities included on Nussbaum's list: practical reason and affiliation.

\section{Conclusion: Modern sport is an unfinished project}

Modern sports, using Habermas's well-known expression (Passerin d'Entreves \& Benhabib, 1997), are an unfinished project. Accordingly, I would argue that although modern sports have become specialized, highly competitive, and technologized because of the instrumental rationality characteristic of modernity, a typically modern moral core element is also alive in them: the claim that there is an intrinsic worth universally shared by all human beings - that is to say, the idea of human dignity. This is the reason why sport is widely regarded as a tool for human development in our society as well as in our sporting institutions. Sport is also a child of modernity from a moral point of view.

I draw on the capabilities approach's conception of dignity in order to show how to use sport as a tool for enhancing and safeguarding peoples' intrinsic worth. Thus, by using Martha Nussbaum's list of human capabilities, I argue that modern sports can serve as a means of promoting, at least, the two main human capabilities: practical reason and affiliation. For instance, this is highly clear in the case of sports supporters. As I show in my paper "The psychobiological bases of sports supporters' behavior" (López Frías, 2012), people in the stands bond together on the basis of a common area of interest: rooting for a particular team Real Madrid's supporters - or following a certain sporting activity - football supporters, so affiliation is promoted through sport.

My claim is that sport managers and sport educators have to learn how to modulate sporting practice and how to highlight its moral values in order to take advantage of their educative potential. To do so, I claim that the Sport for All ideal has to guide their decisions and actions, since it embodies those values at the basis of our democratic-liberal societies - that is to say, the core moral values of modernity. This is the only way to complete the "unfinished project of modern sport."

\section{REFERENCES}

Beashe Beashel, P., \& Taylor, J. (1996). Advanced studies in physical education and sport. Cheltenham, England: Thomas Nelson and Sons.

Bodin, D., \& Sempé, G. (2011). Ethics and sport in Europe. Strasbourg, Germany: Council of Europe Publishing.

Coalter, F. (2010). Sport-for-development: Going beyond the boundary? Sport in Society: Culture, Commerce, Media, Politics, 13(9), 1374-1392.

Conill, J. (1998). Horizontes de economía ética. Madrid: Tecnos.

Dixon, R., \& Nussbaum, M.C. (2011, March). Abortion, dignity, and a capabilities approach. Retrieved from the Chicago Public Law and Legal Theory Working Paper No. 345: http://www.law.uchicago.edu/academics/publiclaw/index.html[15-04-2014]

Eichberg, H. (2010). Bodily democracy: Towards a philosophy of Sport for All. New York, NY: Routledge.

Fraleigh, W. (1984). Right Actions in Sport: Ethics for Contestants. Champaign, ILL: Human Kinetics Publisher. 
Giulianotti, R. (2004). Human rights, globalization and sentimental education: The case of sport. Sport in Society: Culture, Commerce, Media, Politics, 7(3), 355-369.

Grant, E. (2011, 22 September). Equality, dignity, and independence through sport. Retrieved from the United States International Council on Disabilities: http://usicd.wordpress.com/2011/09/22/equality-dignity-and-independencethrough-sport/[20-04-2014]

Kreft, L. (2014). Sport, education and peace. In E. Isidori, F. López Frías, \& A. Muller (Eds.), Philosophy, sport and education (pp. 13-32). Rome, Italy: Sette Cittá.

Levermore, R., \& Beacom, A. (2009). Sport and development: Mapping the field. In R. Levermore, \& A. Beacom (Eds.), Sport and international development (pp. 1-25). New York, NY: Palgrave Macmillan.

López Frías, F. (2012). The psycho-biological bases of sport supporters' behaviour: The virtuous supporter. Sport, ethics and philosophy, 6(4), 423-438.

Moller, V. (2011). The expulsion of Michael Rasmussen from the Tour de France 2007: A manifestation of the ideal of a level playing field? In M. McNamee, \& V. Møller (Eds.), Doping and anti-doping policy in sport. (pp. 200-216). New York, NY: Routledge.

Nussbaum, M. C. (1997). Capabilities and human rights. Fordham Law Review, 66(2), 273-300.

Nussbaum, M. C. (2011). Creating capabilities: The human development approach. Cambridge, MA: Harvard University Press.

Parry, J. (2007). Sport, ethos and education. In J. Parry, M. Nesti, S. Robinson, \& N. Watson, Sport and spirituality: An introduction (pp. 186-200). New York, NY: Routledge.

Passerin d'Entreves, M., \& Benhabib, S. (1997). Habermas and the unfinished project of modernity. Cambridge, MA: MIT Press.

Sen, A. (2005). Human rights and capabilities. Journal of Human Development, 6(2), 151-166.

Simon, R.L. (2007). Good competition and drug-enhanced performance. In W.J. Morgan (Ed.), Ethics in sport (2nd ed.; pp. 245-253). Champaign, IL: Human Kinetics.

Wachter, F. (2002). Education for peace in sport education. In M.A. Holowchak (Ed.), Philosophy of sport: Critical readings, crucial issues (pp. 446-453). Upper Saddle River, NJ: Prentice Hall.

Wamsley, K.B. (2004). Laying Olympism to rest. In J. Bale, \& M.K. Christensen (Eds.), Post-Olympism? Questioning sport in the twenty-first century (pp. 231-242). New York, NY: Berg Publishers.

\section{Appendix I}

The ten central human capabilities are the following:

"1. Life. Being able to live to the end of a human life of normal length; not dying prematurely, or before one's life is so reduced as to be not worth living.

2. Bodily health. Being able to have good health, including reproductive health; to be adequately nourished; to have adequate shelter.

3. Bodily integrity. Being able to move freely from place to place; to be secure against violent assault, including sexual assault and domestic violence; having opportunities for sexual satisfaction and for choice in matters of reproduction.

4. Senses, imagination, and thought. Being able to use the senses, to imagine, think, and reason - and to do these things in a 'truly human' way, a way informed and cultivated by an adequate education, including, but by no means limited to, literacy and basic mathematical and scientific training (...). Being able to have pleasurable experiences and to avoid non-beneficial pain.

5. Emotions. Being able to have attachments to things and people outside ourselves; to love those who love and care for us, to grieve at their absence; in general, to love, to grieve, to experience longing, gratitude, and justified anger. Not having one's emotional development blighted by fear and anxiety. (Supporting this capability means supporting forms of human association that can be shown to be crucial in their development). 
6. Practical reason. Being able to form a conception of the good and to engage in critical reflection about the planning of one's life (...).

7. Affiliation. (A) Being able to live with and toward others, to recognize and show concern for other human beings, to engage in various forms of social interaction; to be able to imagine the situation of another. (Protecting this capability means protecting institutions that constitute and nourish such forms of affiliation, and also protecting the freedom of assembly and political speech). (B) Having the social bases of self-respect and non-humiliation; being able to be treated as a dignified being whose worth is equal to that of others. This entails provisions of non-discrimination on the basis of race, sex, sexual orientation, ethnicity, caste, religion, national origin.

8. Other Species. Being able to live with concern for and in relation to animals, plants, and the world of nature.

9. Play. Being able to laugh, to play, to enjoy recreational activities.

10. Control over one's environment. (A) Political. Being able to participate effectively in political choices that govern one's life; having the right of political participation, protections of free speech and association. (B) Material. Being able to hold property (both land and movable goods), and having property rights on an equal basis with others; having the right to seek employment on an equal basis with others; having the freedom from unwarranted search and seizure. In work, being able to work as a human being, exercising practical reason and entering into meaningful relationships of mutual recognition with other workers". (Nussbaum, 2011, pp. 16-17).

AUTHOR'S ADDRESS: $\quad$ Francisco Javier López Frías

University of Valencia

Mendizabal n176

02640, Almansa (Albacete)

Spain

Email: Francisco.Javier.Lopez@uv.es 